AGRITECH, Vol. 37, No. 3, Agustus 2017, Hal. 263-270.

DOI: http://doi.org/10.22146/agritech.31539 ISSN 0216-0455 (Print), ISSN 2527-3825 (Online)

Tersedia online di https://jurnal.ugm.ac.id/agritech/

\title{
Perbaikan Sifat Laju Transmisi Uap Air dan Antibakteri Edible Film dengan Menggunakan Minyak Sawit dan Jeruk Kunci
}

\author{
Improvement of Water Vapor Transmission Rate and Antibacteria Properties of Edible Film by Using Palm Oil \\ and Citrus mitis
}

\author{
Budi Santoso*, Zuhara Hilda, Gatot Priyanto, Rindit Pambayun \\ Program Studi Teknologi Hasil Pertanian, Jurusan Teknologi Pertanian, Fakultas Pertanian, Universitas Sriwijaya, \\ Jl. Raya Palembang-Prabumulih Km. 32, Ogan Ilir, Sumatera Selatan 30662, Indonesia \\ Email: budiunsri@yahoo.com
}

Submisi: 3 Agustus 2015; Penerimaan: 9 November 2016

\begin{abstract}
ABSTRAK
Tujuan penelitian adalah untuk memperbaiki laju transmisi uap air dan sifat antibakteri edible film dengan menggunakan minyak sawit dan jeruk kunci. Rancangan penelitian yang digunakan adalah rancangan acak lengkap faktorial dengan tiga kali ulangan. Perlakuan terdiri atas konsentrasi ekstrak gambir; 0, 1,5, dan $3(\% \mathrm{~b} / \mathrm{v})$, konsentrasi minyak sawit; $0,1,5$, dan $3(\% \mathrm{v} / \mathrm{v})$, dan $\mathrm{pH}(3,4,5$, dan 6). Hasil penelitian menunjukkan bahwa interaksi ekstrak gambir, minyak sawit, dan derajat keasaman $(\mathrm{pH})$ berpengaruh nyata terhadap kelarutan edible film. Interaksi ekstrak gambir dengan minyak sawit berpengaruh nyata terhadap ketebalan, persen pemanjangan, dan kelarutan edible film. Interaksi minyak sawit dengan derajat keasaman $(\mathrm{pH})$ berpengaruh nyata terhadap kelarutan edible film. Interaksi ekstrak gambir dengan derajat keasaman $(\mathrm{pH})$ berpengaruh nyata terhadap kelarutan edible film. Karakteristik edible film yang dihasilkan adalah ketebalan $0,15-0,28 \mathrm{~mm}$, persen pemanjangan $23,33-87,78 \%$, kelarutan 33,9-49,16\%, laju transmisi uap air 3,43-8,52 g.m $\mathrm{m}^{-2}$.hari ${ }^{-1}$, dan diameter daya hambat terhadap Staphylococcus aureus $0,2-8,2 \mathrm{~mm}$.
\end{abstract}

Kata kunci: Antibakteri; edible film; gambir; minyak sawit; $\mathrm{pH}$

\begin{abstract}
The objective of the research was to improve water vapor transmission rate and antibacterial properties of edible film by using red palm oil and Citrus mitis. The research design was factorial completely randomized design with three replications. There were three studies: the addition of Uncaria gambir Roxb extract, palm oil concentration, and $\mathrm{pH}$ value at the concentration $0,1.5$, and $3(\% \mathrm{w} / \mathrm{v}) ; 0,1.5$, and $3(\% \mathrm{v} / \mathrm{v})$; and $3,4,5$, and 6 respectively. The results showed that interaction of Uncaria gambir Roxb extract, palm oil and $\mathrm{pH}$ had significant effected on solubility of edible film. Interaction of Uncaria gambir Roxb and palm oil had significant effected on thickness, percentage of elongation and solubility of edible film. Interaction of Uncaria gambir Roxb and $\mathrm{pH}$ had significant effected on solubility of edible film. Characteristic of edible film was produced thickness 0.15 to $0.28 \mathrm{~mm}$, percentage of elongation 23.33 to $87.78 \%$, solubility 33.9 to $49.16 \%$, water vapor transmission rate 3.43 to $8.52 \mathrm{~g} \cdot \mathrm{m}^{-2} . \mathrm{d}^{-1}$, and inhibition zone for Staphylococcus aureus 0.2 to $8.2 \mathrm{~mm}$.
\end{abstract}

Keywords: Antibacterial; edible film; palm oil; pH; Uncaria gambir Roxb 


\section{PENDAHULUAN}

Pengembangan edible film sebagai bahan kemasan pangan yang aman untuk dikonsumsi oleh manusia terus mengalami peningkatan dari tahun ke tahun. Fokus penelitian yang sedang dikembangkan saat ini adalah penggunaan bahan-bahan biopolymer lokal seperti pati ganyong, ubi kayu, dan gadung serta penambahan senyawa antibakteri alami berbasis lokal seperti ekstrak gambir, asap cair, dan ekstrak kayu secang.

Penelitian Santoso dkk. (2012) mengungkapkan bahwa karakteristik edible film pati ganyong yang dikompositkan dengan lilin lebah memiliki nilai laju transmisi uap air 18,25 g.m ${ }^{-2} \cdot$ hari $^{-1}$ dengan persen pemanjangan 36,98\%. Menurut Japanese International Standard (JIS) (1975) nilai laju transmisi uap air dan persen pemanjangan edible film maksimal $10 \mathrm{~g} \cdot \mathrm{m}^{-2}$.hari-1 dan minimal $70 \%$. Selain itu, secara fisik permukaan edible film yang dihasilkan kasar dan muncul bintik-bintik lilin lebah yang tidak terikat secara sempurna. Secara teori, lilin lebah merupakan komponen yang bersifat non polar atau hidropobik dan seharusnya penambahan lilin lebah dalam matrik film akan menurun laju transmisi uap air edible film, namun hal ini tidak terjadi karena lilin lebah berbentuk padat dan sangat mudah mengkristal pada suhu ruang. Bentuk kristal lilin lebah menyebabkan ikatan komplek dalam matrik edible film tidak terjadi secara sempurna dengan molekul lain yang mengakibatkan distribusi lilin lebah tidak merata. Hal ini sesuai yang diungkapkan oleh Krochta dkk. (1994), bahwa efektifitas karakteristik edible film tergantung pada kekuatan dari komponen dan keseragaman distribusi dari substansi hidropobik dalam suspensi edible film. Lilin lebah merupakan jenis asam lemak jenuh sehingga untuk membentuk ikatan dengan senyawa lain lebih sulit dibanding dengan asam lemak tidak jenuh. Untuk mengatasi permasalahan ini, maka salah satu cara yang dapat dilakukan adalah penggunaan asam lemak tidak jenuh, karena asam ini berwujud cair pada suhu kamar sehingga pada saat pencampuran dalam formulasi edile film tersebut bisa merata. Menurut Tanaka dkk. (2001) bahwa penambahan asam lemak tidak jenuh pada larutan edible film memberikan pengaruh yang signifikan dalam menurunkan nilai laju transmisi uap air. Manab (2008) melaporkan bahwa penambahan minyak sawit sebesar 10\% dapat menurunkan laju transmisi uap air edible film secara signifikan.

Selain perbaikan laju transmisi uap air, edible film juga telah dikembangkan sifat fungsionalnya, yaitu edible film antibakteri dengan pemanfaatan ekstrak gambir sebagai senyawa antibakteri alami. Santoso (2011) menjelaskan bahwa penggunaan ekstrak gambir sampai pada konsentrasi $4 \%$ (b/v) yang dikombinasikan dengan protein pada pembuatan edible film berbasis pati termodifikasi tidak memiliki sifat antibakteri. Secara teori, hal ini dapat dijelaskan bahwa: pertama, ekstrak gambir mengandung senyawa katekin yang stabil pada $\mathrm{pH}$ rendah sedangkan pada penelitian Santoso (2011) tidak ada pengaturan $\mathrm{pH}$ atau $\mathrm{pH}$ netral. Kedua, protein memiliki afinitas tinggi terhadap senyawa katekin, sehingga menurunkan sifat antibakteri dari senyawa katekin. Santoso dkk. (2014) menambahkan bahwa edible film dengan komposisi ekstrak gambir, protein, dan pengaturan $\mathrm{pH}$ dengan $\mathrm{HCl}$ tidak memiliki sifat antibakteri. Pengaturan $\mathrm{pH}$ pada penelitian Santoso dkk. (2014) dilakukan pada pH 5, 6, 7, dan 9. Pada kondisi $\mathrm{pH}$ ini terdapat dua permasalahan, yaitu: pertama, $\mathrm{pH}$ yang digunakan tidak bersifat asam sehingga senyawa katekin tidak stabil sebagai antibakteri dan kedua $\mathrm{pH}$ yang digunakan termasuk interval $\mathrm{pH}$ isoelektrik, sehingga protein akan membentuk endapan pada matrik film.

Perbaikan sifat laju transmisi uap air dan antibakteri edible film dapat dilakukan dengan penggantian komponen lilin lebah dengan senyawa hidropobik yang bersifat tidak mudah mengkristal pada suhu kamar dan mengandung asam lemak tidak jenuh seperti minyak sawit dan pengaturan konsentrasi ekstrak gambir dan derajat keasaman $(\mathrm{pH})$ suspensi edible film yang disesuaikan dengan kondisi optimal senyawa katekin dalam ekstrak gambir.

\section{METODE PENELITIAN}

\section{Alat dan Bahan}

Alat-alat yang digunakan: (1) Micrometer (Roch) (A281500504, Sisaku SHO Ltd, Japan), Testing Machine MPY (Type: PA-104-30, Ltd Tokyo, Japan), (2) gas transmission rate tester speedivac 2, (3) water vapor transmission rate tester Bergerlahr, (4) Cawan petri dengan diameter $15 \mathrm{~cm}$, (5) desikator, (6) Hot plate merk Torrey Pines Scientific, (7) Incubator shaker, (8) Kertas saring Whatman no.4, (9) Magnetic stirrer, (10) Neraca analitik (merk Ohaus corp. Pine Brook, NJ USA), (11) Oven pengering, (12) pH meter (merk HI9024 microcomputer $\mathrm{pH}$ meter), (13) Pompa vakum (Model: DOA-P504-BN), dan (14) Sentrifugasi (15 MI 3000 rpm DSC 200T).

Bahan-bahan yang digunakan meliputi: (1) Gambir (Uncaria gambir Roxb) berasal dari Kecamatan Babat Toman Kabupaten Musi Banyusin Sumatera Selatan, (2) Air akuades, (3) CMC, (4) Gliserol, (5) Jeruk Kunci (Citrus mitis) yang diperoleh dari Indralaya, (6) Minyak sawit, (7) $\mathrm{NaCl}$, (8) Nutrient Broth, dan (9) Pati ganyong yang diperoleh dari Indralaya.

\section{Rancangan Penelitian}

Penelitian ini menggunakan Rancangan Acak Lengkap Faktorial (RALF) dengan tiga kali ulangan. Faktor perlakuan terdiri atas: konsentrasi ekstrak gambir $(A), A_{1}=0, A_{2}=1,5$ 
dan $\mathrm{A}_{3}=3 \%(\mathrm{~b} / \mathrm{v})$, konsentrasi minyak sawit $(\mathrm{B}), \mathrm{B}_{1}=0, \mathrm{~B}_{2}$ $=1,5$ dan $\mathrm{B}_{3}=3 \%(\mathrm{v} / \mathrm{v})$, dan derajat keasaman $(\mathrm{pH})(\mathrm{C}), \mathrm{C}_{1}=$ $3, \mathrm{C}_{2}=4, \mathrm{C}_{3}=5$ dan $\mathrm{C}_{4}=6$. Parameter yang diamati adalah persen pemanjangan (ASTM, 1997), ketebalan (mm) metode Microcal Messmer (ASTM, 1997), kelarutan edible film dalam air (Laohakunjit dan Noomhorm, 2004), laju transmisi uap air (ASTM, 1997) dan sifat antibakteri (Campos dkk., 2011). Perlakuan yang berpengaruh nyata dilakukan uji lanjut BNJ 5\% dengan menggunakan program SAS versi window 9.

\section{Cara Kerja}

Penelitian ini dilakukan dengan dua tahap, yaitu pembuatan ekstrak jeruk kunci (Marta dkk., 2007) dan pembuatan edible film (Santoso dkk., 2011).

\section{Pembuatan Sari Buah Jeruk Kunci}

Jeruk kunci disortasi, jeruk yang busuk dan yang terlalu muda dibuang, selanjutnya dicuci menggunakan air bersih kemudian ditiriskan. Jeruk kunci dikupas dan dibuang bijinya kemudian diperas dengan menggunakan alat peras jeruk kemudian sari jeruk kunci disaring menggunakan kain blacu.

\section{Pembuatan Edible Film}

Pati ganyong sebanyak $4 \mathrm{~g}$ dimasukan dalam beaker gelas dan tambahkan air akuades sampai batas $300 \mathrm{~mL}$ kemudian suspensi pati diaduk menggunakan magnetik stirrer pada kecepatan 700 rpm dan dipanaskan dengan hot plate pada suhu $65^{\circ} \mathrm{C}$. Setelah terjadi gelatinisasi sempurna (perubahan warna putih menjadi transparan atau bening) ditambahkan gliserol sebanyak 3\% (v/v). Suspensi ditambahkan sari jeruk kunci sesuai dengan perlakuan tingkatan $\mathrm{pH}(3,4,5,6)$ dan diaduk sampai homogen. Penambahan ekstrak gambir sesuai dengan perlakuan $(0,1,5$, dan $3 \%(b / v))$ sedikit demi sedikit dengan tetap dilakukan pengadukan selama 5 menit dengan kecepatan $450 \mathrm{rpm}$ dilanjutkan dengan penambahan CMC 1,5 g secara sedikit demi sedikit sambil tetap dilakukan pengadukan dengan kecepatan tetap selama 7 menit dan minyak sawit sesuai dengan perlakuan $(0,1,5$, dan 3\% (v/v). Setelah tercampur secara sempurna atau homogen, suspensi dilakukan degassing dengan menggunakan pompa vakum selama kurang lebih 1 jam dengan tekanan $680 \mathrm{mmHg}$. Suspensi diletakan dalam cawan Petri dengan diameter $15 \mathrm{~cm}$ sebanyak $30 \mathrm{~mL}$. Suspensi dikeringkan dalam oven pengering dengan suhu $70{ }^{\circ} \mathrm{C}$ selama 24 jam. Edible film diangkat dari cawan petri kemudian diletakan dalam desikator selama 24 jam dan siap untuk dianalisa.

\section{HASIL DAN PEMBAHASAN}

\section{Ketebalan}

Nilai rata-rata ketebalan edible film berkisar antara 0,15 hingga $0,37 \mathrm{~mm}$. Ketebalan terendah pada perlakuan $\mathrm{A}_{1} \mathrm{~B}_{1} \mathrm{C}_{2}$ dan tertinggi $\mathrm{A}_{3} \mathrm{~B}_{3} \mathrm{C}_{3}$. Ketebalan edible film yang dihasilkan sesuaikan Japan International Standard (JIS) (1975) yaitu maksimal 0,25 mm. Analisis keragaman menunjukkan bahwa perlakuan ekstrak gambir, minyak sawit, dan interaksi perlakuan ekstrak gambir dengan minyak sawit berpengaruh nyata terhadap ketebalan edible film, sedangkan derajat keasaman dan perlakuan interaksi lainnya berpengaruh tidak nyata. Hasil uji lanjut BNJ perlakuan ekstrak gambir terhadap ketebalan, persen pemanjangan, dan kelarutan edible film seperti pada Tabel 1.

Ketebalan edible film makin meningkat seiring dengan meningkatnya konsentrasi ekstrak gambir seperti yang disajikan pada uji lanjut BNJ (Tabel 1). Ekstrak gambir mengandung senyawa katekin yang dapat membentuk kristal pada kondisi kering. Bentuk kristal ini merupakan padatan yang berpengaruh terhadap ketebalan edible film, makin tinggi total padatan dalam matrik edible film maka ketebalan edible film makin meningkat. Lucida (2006) menjelaskan bahwa katekin mempunyai sifat tidak mudah larut dalam air dingin, tetapi larut dalam air panas dan bila kering berbentuk kristal yang berwarna kuning. Menurut Huri dan Nisa (2014) penambahan konsentrasi ekstrak ampas kulit apel yang semakin tinggi menyebabkan kenaikan total padatan dalam edible film, sehingga terjadi peningkatkan ketebalan edible film.

Hasil uji lanjut BNJ (Tabel 2) menunjukkan bahwa penambahan minyak sawit sebanyak $1,5 \%$ berbeda nyata dengan tanpa penambahan minyak sawit dan berbeda tidak

Tabel 1. Uji BNJ pengaruh konsentrasi ekstrak gambir terhadap ketebalan, persen pemanjangan, dan kelarutan edible film

\begin{tabular}{cccc}
\hline \multicolumn{1}{c}{ Perlakuan } & $\begin{array}{c}\text { Ketebalan } \\
(\mathrm{mm})\end{array}$ & $\begin{array}{c}\text { Pemanjangan } \\
(\%)\end{array}$ & $\begin{array}{c}\text { Kelarutan } \\
(\%)\end{array}$ \\
\hline $\mathrm{A}_{1}$ (ekstrak gambir 0\%) & $0,18^{\mathrm{a}}$ & $37,41^{\mathrm{a}}$ & $46,90^{\mathrm{a}}$ \\
$\mathrm{A}_{2}$ (ekstrak gambir 1,5\%) & $0,20^{\mathrm{a}}$ & $74,17^{\mathrm{b}}$ & $40,29^{\mathrm{b}}$ \\
$\mathrm{A}_{3}$ (ekstrak gambir 3\%) & $0,31^{\mathrm{b}}$ & $82,87^{\mathrm{c}}$ & $39,03^{\mathrm{c}}$ \\
\hline
\end{tabular}

Keterangan: Angka-angka yang diikuti oleh huruf yang sama pada kolom yang sama berarti berbeda tidak nyata $(\alpha<5 \%)$.

Tabel 2. Uji BNJ pengaruh konsentrasi minyak sawit terhadap ketebalan, persen pemanjangan, dan kelarutan edible film

\begin{tabular}{cccc}
\hline Perlakuan & $\begin{array}{c}\text { Ketebalan } \\
(\mathrm{mm})\end{array}$ & $\begin{array}{c}\text { Persen } \\
\text { pemanjangan }(\%)\end{array}$ & $\begin{array}{c}\text { Kelarutan } \\
(\%)\end{array}$ \\
\hline $\mathrm{B}_{1}$ (minyak sawit 0\%) & $0,20^{\mathrm{a}}$ & $68,33^{\mathrm{a}}$ & $44,24^{\mathrm{a}}$ \\
$\mathrm{B}_{2}$ (minyak sawit 1,5\%) & $0,24^{\mathrm{b}}$ & $66,67^{\mathrm{b}}$ & $42,33^{\mathrm{b}}$ \\
$\mathrm{B}_{3}$ (minyak sawit 3\%) & $0,26^{\mathrm{b}}$ & $59,44^{\mathrm{b}}$ & $39,66^{\mathrm{c}}$ \\
\hline
\end{tabular}

Keterangan: Angka-angka yang diikuti oleh huruf yang sama pada kolom yang sama berarti berbeda tidak nyata $(\alpha<5 \%)$. 
nyata dengan penambahan minyak sawit 3\%. Semakin tinggi konsentrasi minyak sawit yang digunakan semakin meningkat nilai ketebalan edible film. Manab (2008) menjelaskan bahwa penggunaan minyak kelapa sawit dalam formulasi edible film berbasis protein dapat menurunkan laju transmisi uap secara signifikan, hal ini disebabkan asam lemak tidak jenuh minyak kelapa sawit dapat meregulasi asam-asam lemak dalam struktur matrik edible film lebih merata dan padat. Hasil penelitian ini menunjukkan bahwa minyak sawit berpengaruh terhadap peningkatan kepadatan edible film, kepadatan matrik edible film berpengaruh terhadap ketebalannya.

Hasil uji BNJ (Tabel 3) menunjukkan bahwa interaksi perlakuan ekstrak gambir dengan minyak sawit makin tinggi konsentrasi keduanya maka makin tinggi ketebalan edible film. Diketahui bahwa senyawa katekin membentuk kristal pada kondisi kering yang berpengaruh terhadap penambahan total padatan dalam matrik edible film. Menurut Manab (2008), minyak sawit merupakan asam lemak tidak jenuh dan berbentuk cairan pada suhu kamar, sehingga dengan sifat ini minyak sawit dapat menyebar merata dalam matrik edible film dan hal ini berpengaruh keterhadap peningkatan kepadatan dan ketebalan edible film yang terbentuk. Jadi kombinasi antara ekstrak gambir dengan minyak sawit bersinergis dalam meningkatkan ketebalan edible film.

Hasil uji BNJ seperti pada Tabel 1 menunjukkan bahwa perlakuan penambahan ekstrak gambir konsentrasi satu dengan yang lainnya berbeda nyata terhadap nilai persen pemanjangan edible film. Semakin tinggi konsentrasi ekstrak gambir yang ditambahkan persen pemanjangan edible film semakin meningkat. Hal ini disebabkan senyawa katekin yang dikandung oleh ekstrak gambir memiliki gugus hidroksil $(\mathrm{OH})$ dimana gugus $\mathrm{OH}$ ini dapat mengikat air, sehingga makin tinggi konsentrasi ekstrak gambir maka makin banyak

Tabel 3. Uji BNJ pengaruh interaksi perlakuan ekstrak gambir dengan minyak sawit terhadap ketebalan, persen pemanjangan, dan kelarutan edible film

\begin{tabular}{cccc}
\hline Perlakuan & $\begin{array}{c}\text { Ketebalan } \\
(\mathrm{mm})\end{array}$ & $\begin{array}{c}\text { Persen pemanjangan } \\
(\%)\end{array}$ & Kelarutan $(\%)$ \\
\hline $\mathrm{A}_{1} \mathrm{~B}_{1}$ & $0,16^{\mathrm{a}}$ & $45,28^{\mathrm{c}}$ & $48,09^{\mathrm{d}}$ \\
$\mathrm{A}_{1} \mathrm{~B}_{2}$ & $0,18^{\mathrm{b}}$ & $41,11^{\mathrm{b}}$ & $47,14^{\mathrm{d}}$ \\
$\mathrm{A}_{2} \mathrm{~B}_{1}$ & $0,20^{\mathrm{c}}$ & $73,33^{\mathrm{e}}$ & $44,06^{\mathrm{c}}$ \\
$\mathrm{A}_{1} \mathrm{~B}_{3}$ & $0,20^{\mathrm{cd}}$ & $25,83^{\mathrm{a}}$ & $45,49^{\mathrm{c}}$ \\
$\mathrm{A}_{2} \mathrm{~B}_{3}$ & $0,21^{\mathrm{d}}$ & $72,22^{\mathrm{d}}$ & $36,69^{\mathrm{a}}$ \\
$\mathrm{A}_{2} \mathrm{~B}_{2}$ & $0,21^{\mathrm{d}}$ & $76,94^{\mathrm{f}}$ & $40,12^{\mathrm{b}}$ \\
$\mathrm{A}_{3} \mathrm{~B}_{1}$ & $0,25^{\mathrm{e}}$ & $86,39^{\mathrm{i}}$ & $40,58^{\mathrm{b}}$ \\
$\mathrm{A}_{3} \mathrm{~B}_{2}$ & $0,33^{\mathrm{f}}$ & $81,84^{\mathrm{h}}$ & $39,73^{\mathrm{b}}$ \\
$\mathrm{A}_{3} \mathrm{~B}_{3}$ & $0,36^{\mathrm{g}}$ & $80,28^{\mathrm{g}}$ & $36,79^{\mathrm{a}}$ \\
\hline
\end{tabular}

Keterangan: Angka-angka yang diikuti oleh huruf yang sama pada kolom yang sama berarti berbeda tidak nyata $(\alpha<5 \%)$. gugus $\mathrm{OH}$ yang dapat mengikat air dalam matrik edible film (Pambayun, 2008) Jumlah air yang terikat dalam matrik berpengaruh terhadap peningkatan elastisitas edible film. Rodriguez dkk. (2006) menjelaskan bahwa gliserol yang banyak mengandung gugus $\mathrm{OH}$ dalam sistem matrik edible film dapat meningkatkan laju transmisi uap air dan persen pemanjangan edible film.

Hasil uji BNJ (Tabel 2) menunjukkan bahwa makin tinggi konsentrasi minyak sawit persen pemanjangan edible film makin menurun. Minyak sawit mengandung asam lemak tidak jenuh yang bersifat hidropobik dan berbentuk cair pada suhu kamar. Asam lemak tak jenuh dapat meregulasi asam-asam lemak dalam matrik edible film sehingga merata dan padat yang menyebabkan tingkat elastisitas edible film menurun. Menurut Martin-Polo dkk. (1992), penggunaan lipid cair dalam formulasi film dapat membentuk struktur edible film yang lebih padat. Manab (2008) menambahkan bahwa asam lemak tak jenuh rantai panjang dalam minyak kelapa sawit memiliki sifat hidrofobisitas yang dapat meregulasi komposisi asam lemak dalam struktur edible film sehingga mobilitasnya meningkat dan hal ini menyebabkan penurunan laju transmisi uap air. Jimenez dkk. (2010) menjelaskan bahwa edible film yang dibentuk dari hidroksipropil metilselulosa (HPMC) dengan asam lemak jenuh dan asam lemak tidak jenuh dapat membentuk edible film dengan laju transmisi uap air rendah, namun lebih rapuh atau mudah retak, kurang elastis, warna agak buram, dan kurang mengkilap.

Interaksi perlakuan ekstrak gambir dengan minyak sawit seperti yang disajikan pada Tabel 3 menunjukkan bahwa kombinasi ekstrak gambir dengan konsentrasi tinggi dengan minyak sawit rendah menghasilkan edible film yang memiliki persen pemajangan tinggi dan begitu juga sebaliknya. Hal ini menandakan bahwa peran masing-masing perlakuan sangat besar terhadap pembentukan karakteristik edible film terutama pada persen pemanjangan.

\section{Kelarutan}

Nilai rata-rata kelarutan edible film berkisar antara 33,9 hingga 49,16\%. Kelarutan edible film terendah pada perlakuan $\mathrm{A}_{3} \mathrm{~B}_{3} \mathrm{C}_{1}$ dan tertinggi $\mathrm{A}_{1} \mathrm{~B}_{1} \mathrm{C}_{3}$. Analisis keragaman terhadap kelarutan edible film menunjukkan bahwa perlakuan ekstrak gambir, minyak sawit, derajat keasaman dan semua perlakuan interaksinya berpengaruh nyata.

Uji BNJ (Tabel 1) menunjukkan bahwa perlakuan penambahan ekstrak gambir konsentrasi satu dengan yang lainnya berbeda nyata terhadap nilai kelarutan edible film. Semakin tinggi konsentrasi ekstrak gambir semakin rendah tingkat kelarutan edible film. Hal ini disebabkan senyawa katekin dalam gambir walaupun banyak mengandung gugus hidroksil $(\mathrm{OH})$, namun senyawa ini bersifat semi polar. Menurut Lucida (2006) senyawa katekin bersifat asam lemah 
Tabel 4. Uji BNJ pengaruh interaksi perlakuan minyak sawit dengan derajat keasaman $(\mathrm{pH})$ terhadap kelarutan edible film

\begin{tabular}{cc}
\hline Perlakuan & Kelarutan $(\%)$ \\
\hline $\mathrm{B}_{3} \mathrm{C}_{3}$ & $38,07^{\mathrm{a}}$ \\
$\mathrm{B}_{3} \mathrm{C}_{4}$ & $39,15^{\mathrm{ab}}$ \\
$\mathrm{B}_{3} \mathrm{C}_{2}$ & $40,02^{\mathrm{ab}}$ \\
$\mathrm{B}_{2} \mathrm{C}_{3}$ & $41,23^{\mathrm{b}}$ \\
$\mathrm{B}_{3} \mathrm{C}_{1}$ & $41,30^{8 \mathrm{~b}}$ \\
$\mathrm{~B}_{2} \mathrm{C}_{4}$ & $41,99^{\mathrm{b}}$ \\
$\mathrm{B}_{1} \mathrm{C}_{2}$ & $40,58^{\mathrm{bc}}$ \\
$\mathrm{B}_{2} \mathrm{C}_{2}$ & $43,31^{\mathrm{bc}}$ \\
$\mathrm{B}_{2} \mathrm{C}_{1}$ & $43,33^{\mathrm{bc}}$ \\
$\mathrm{B}_{1} \mathrm{C}_{4}$ & $43,95^{\mathrm{c}}$ \\
$\mathrm{B}_{1} \mathrm{C}_{1}$ & $44,41^{\mathrm{c}}$ \\
$\mathrm{B}_{1} \mathrm{C}_{3}$ & $46,61^{\mathrm{c}}$ \\
\hline
\end{tabular}

Keterangan: Angka-angka yang diikuti oleh huruf yang sama pada kolom yang sama berarti berbeda tidak nyata $(\alpha<5 \%)$.

(pKa $1=7,72$ dan pKa $2=10,22$ ) sukar larut dalam air dan sangat tidak stabil pada udara terbuka. Tabel 2 menunjukkan bahwa makin tinggi konsentrasi minyak sawit makin turun kelarutan edible film. Hal ini berkaitan dengan sifat dari minyak sawit yang bersifat hidropobik. Kelarutan edible film pada perlakuan interaksi ekstrak gambir dengan minyak sawit seperti pada Tabel 3 menunjukkan bahwa ekstrak gambir dengan konsentrasi tinggi yang dikombinasikan dengan perlakuan minyak sawit dengan konsentrasi tinggi menghasilkan edible film kelarutan rendah. Santoso (2011) dan Manab (2008) masing-masing mengungkapkan bahwa esktrak gambir dan minyak sawit berpengaruh nyata terhadap penurunan kelarutan edible film.

Hasil uji BNJ (Tabel 4) menunjukkan bahwa kecenderungan nilai kelarutan edible film semakin menurun dengan semakin tinggi konsentrasi minyak sawit dan nilai derajat keasaman. Hal ini disebabkan hidrolisis asam lemak tidak jenuh dalam minyak sawit sulit terjadi pada kondisi pH mendekati netral, sehingga gliserol yang terbentuk dari hasil reaksi hidrolisis tersebut rendah dan hal ini berpengaruh terhadap kelarutan edible film. Menurut Setyopratomo (2012) menjelaskan bahwa proses hidrolisis minyak sawit dengan menggunakan katalisator asam menghasilkan asam lemak dan gliserol.

Tabel 5 menunjukkan bahwa kecenderungan kelarutan edible film semakin menurun dengan semakin meningkatnya konsentrasi ekstrak gambir dan semakin turunnya nilai derajat keasaman dan berlaku sebaliknya. Hal ini disebabkan esktrak gambir mengandung senyawa katekin yang bersifat
Tabel 5. Uji BNJ pengaruh interaksi perlakuan ekstrak gambir dengan derajat keasaman $(\mathrm{pH})$ terhadap kelarutan edible film

\begin{tabular}{cc}
\hline Perlakuan & Kelarutan (\%) \\
\hline $\mathrm{A}_{3} \mathrm{C}_{2}$ & $37,25^{\mathrm{a}}$ \\
$\mathrm{A}_{3} \mathrm{C}_{4}$ & $37,96^{\mathrm{a}}$ \\
$\mathrm{A}_{3} \mathrm{C}_{3}$ & $38,53^{\mathrm{ab}}$ \\
$\mathrm{A}_{3} \mathrm{C}_{4}$ & $38,83^{\mathrm{ab}}$ \\
$\mathrm{A}_{2} \mathrm{C}_{3}$ & $40,43^{\mathrm{b}}$ \\
$\mathrm{A}_{3} \mathrm{C}_{1}$ & $40,77^{\mathrm{b}}$ \\
$\mathrm{A}_{2} \mathrm{C}_{2}$ & $41,52^{\mathrm{b}}$ \\
$\mathrm{A}_{3} \mathrm{C}_{2}$ & $41,99^{\mathrm{b}}$ \\
$\mathrm{A}_{1} \mathrm{C}_{2}$ & $46,08^{\mathrm{c}}$ \\
$\mathrm{A}_{1} \mathrm{C}_{3}$ & $46,61^{\mathrm{c}}$ \\
$\mathrm{A}_{1} \mathrm{C}_{1}$ & $47,17^{\mathrm{c}}$ \\
$\mathrm{A}_{1} \mathrm{C}_{4}$ & $47,76^{\mathrm{c}}$ \\
\hline
\end{tabular}

Keterangan: Angka-angka yang diikuti oleh huruf yang sama pada kolom yang sama berarti berbeda tidak nyata $(\alpha<5 \%)$.

semipolar dan stabil pada kondisi asam. Menurut Lucida (2006) bahwa senyawa katekin dari ekstrak gambir bersifat mudah teroksidasi pada $\mathrm{pH}$ mendekati netral $(\mathrm{pH} 6,9)$ dan stabil pada $\mathrm{pH}$ lebih rendah ( $\mathrm{pH} 2,8$ dan 4,9). Pambayun dkk. (2007) menambahkan bahwa senyawa katekin dari ekstrak gambir bersifat semipolar.

Tabel 6 menunjukkan bahwa kelarutan edible film cenderung mengalami penurunan dengan kombinasi perlakuan konsentrasi ekstrak gambir tinggi (senyawa katekin), minyak sawit rendah, dan derajat keasaman rendah. Hal ini disebabkan dalam matrik edible film yang terbentuk ikatan komplek antara senyawa katekin-gliserol-CMCminyak sawit. Mekanisme ikatan komplek matrik edible film terjadi gugus hidroksil $(\mathrm{OH})$ dalam senyawa katekin berikatan dengan $\mathrm{OH}$ dari senyawa gliserol dan gugus $\mathrm{OH}$ gliserol berikatan dengan CMC pada sisi hidrofilik sedangkan sisi hidropobik CMC berikatan dengan senyawa trigliserida dalam minyak sawit. Peranan masing-masing senyawa pembentuk ikatan saling sinergis, telah diketahui bahwa senyawa katekin bersifat semipolar dan stabil pada $\mathrm{pH}$ rendah sedangkan senyawa trigeliserida dalam minyak sawit bersifat non polar. Rahim dkk. (2010) menjelaskan bahwa peningkatan konsentrasi minyak sawit dalam pembuatan edible film pati aren dapat menurunkan laju transmisi uap air edible film yang dihasilkan karena sifat hidropobik yang dimiliki oleh minyak sawit. Santoso (2011) mengungkapkan bahwa semakin tinggi konsentrasi ekstrak gambir dapat menyebabkan penurunan kelarutan edible film. 
Tabel 6. Uji BNJ pengaruh interaksi perlakuan ekstrak gambir, minyak sawit, dan derajat keasaman $(\mathrm{pH})$ terhadap kelarutan edible film

\begin{tabular}{|c|c|}
\hline Perlakuan & Kelarutan (\%) \\
\hline $\mathrm{A}_{3} \mathrm{~B}_{1} \mathrm{C}_{2}$ & $33,9^{\mathrm{a}}$ \\
\hline $\mathrm{A}_{3} \mathrm{~B}_{3} \mathrm{C}_{3}$ & $34,16^{\mathrm{a}}$ \\
\hline $\mathrm{A}_{2} \mathrm{~B}_{3} \mathrm{C}_{3}$ & $34,77^{\mathrm{ab}}$ \\
\hline $\mathrm{A}_{2} \mathrm{~B}_{3} \mathrm{C}_{4}$ & $34,92^{\mathrm{ab}}$ \\
\hline $\mathrm{A}_{3} \mathrm{~B}_{3} \mathrm{C}_{4}$ & $35,38^{\mathrm{ab}}$ \\
\hline $\mathrm{A}_{2} \mathrm{~B}_{3} \mathrm{C}_{2}$ & $37,20^{\mathrm{ab}}$ \\
\hline $\mathrm{A}_{3} \mathrm{~B}_{3} \mathrm{C}_{2}$ & $38,11^{\mathrm{ab}}$ \\
\hline $\mathrm{A}_{3} \mathrm{~B}_{2} \mathrm{C}_{4}$ & $38,12^{\mathrm{ab}}$ \\
\hline $\mathrm{A}_{2} \mathrm{~B}_{2} \mathrm{C}_{4}$ & $38,72^{\mathrm{b}}$ \\
\hline $\mathrm{A}_{3} \mathrm{~B}_{2} \mathrm{C}_{3}$ & $38,84^{b}$ \\
\hline $\mathrm{A}_{2} \mathrm{~B}_{2} \mathrm{C}_{1}$ & $39,17^{\mathrm{b}}$ \\
\hline $\mathrm{A}_{2} \mathrm{~B}_{2} \mathrm{C}_{3}$ & $39,49^{b}$ \\
\hline $\mathrm{A}_{3} \mathrm{~B}_{3} \mathrm{C}_{1}$ & $39,51^{b}$ \\
\hline $\mathrm{A}_{3} \mathrm{~B}_{2} \mathrm{C}_{2}$ & $39,73^{b}$ \\
\hline $\mathrm{A}_{2} \mathrm{~B}_{3} \mathrm{C}_{1}$ & $39,88^{b}$ \\
\hline $\mathrm{A}_{2} \mathrm{~B}_{1} \mathrm{C}_{4}$ & $40,24^{b}$ \\
\hline $\mathrm{A}_{3} \mathrm{~B}_{2} \mathrm{C}_{1}$ & $42,22^{\mathrm{bc}}$ \\
\hline $\mathrm{A}_{2} \mathrm{~B}_{1} \mathrm{C}_{1}$ & $42,24^{\mathrm{bc}}$ \\
\hline $\mathrm{A}_{3} \mathrm{~B}_{1} \mathrm{C}_{3}$ & $42,59^{\mathrm{bc}}$ \\
\hline $\mathrm{A}_{3} \mathrm{~B}_{1} \mathrm{C}_{1}$ & $42,84^{\mathrm{bc}}$ \\
\hline $\mathrm{A}_{3} \mathrm{~B}_{1} \mathrm{C}_{4}$ & $42,98^{\mathrm{bc}}$ \\
\hline $\mathrm{A}_{2} \mathrm{~B}_{2} \mathrm{C}_{2}$ & $43,10^{\mathrm{bc}}$ \\
\hline $\mathrm{A}_{1} \mathrm{~B}_{3} \mathrm{C}_{1}$ & $44,74^{\mathrm{c}}$ \\
\hline $\mathrm{A}_{1} \mathrm{~B}_{3} \mathrm{C}_{2}$ & $44,75^{\mathrm{c}}$ \\
\hline $\mathrm{A}_{1} \mathrm{~B}_{3} \mathrm{C}_{3}$ & $45,29^{\mathrm{c}}$ \\
\hline $\mathrm{A}_{1} \mathrm{~B}_{2} \mathrm{C}_{3}$ & $45,36^{c}$ \\
\hline $\mathrm{A}_{2} \mathrm{~B}_{1} \mathrm{C}_{2}$ & $45,68^{\mathrm{c}}$ \\
\hline $\mathrm{A}_{1} \mathrm{~B}_{1} \mathrm{C}_{2}$ & $46,40^{c}$ \\
\hline $\mathrm{A}_{1} \mathrm{~B}_{2} \mathrm{C}_{2}$ & $47,10^{\mathrm{c}}$ \\
\hline $\mathrm{A}_{1} \mathrm{~B}_{3} \mathrm{C}_{4}$ & $47,16^{\mathrm{c}}$ \\
\hline $\mathrm{A}_{1} \mathrm{~B}_{2} \mathrm{C}_{4}$ & $47,46^{\mathrm{c}}$ \\
\hline $\mathrm{A}_{2} \mathrm{~B}_{1} \mathrm{C}_{3}$ & $48,06^{c}$ \\
\hline $\mathrm{A}_{1} \mathrm{~B}_{1} \mathrm{C}_{1}$ & $48,14^{\mathrm{c}}$ \\
\hline $\mathrm{A}_{1} \mathrm{~B}_{2} \mathrm{C}_{1}$ & $48,61^{\mathrm{c}}$ \\
\hline $\mathrm{A}_{1} \mathrm{~B}_{1} \mathrm{C}_{4}$ & $48,64^{\mathrm{c}}$ \\
\hline $\mathrm{A}_{1} \mathrm{~B}_{1} \mathrm{C}_{3}$ & $49,16^{\mathrm{c}}$ \\
\hline
\end{tabular}

Keterangan: Angka-angka yang diikuti oleh huruf yang sama pada kolom yang sama berarti berbeda tidak nyata $(\alpha<5 \%)$.

\section{Laju Transmisi Uap Air}

Nilai rata-rata laju transmisi uap air edible film tertinggi adalah 8,52 dan terendah sebesar 3,43 g.m $\mathrm{m}^{-2} \cdot$ hari $^{-1}$. Laju transmisi uap air edible film yang dihasilkan memenuhi Japan International Standard (JIS) 1975 yaitu maksimal 10 g.m². hari $^{-1}$. Nilai rata-rata laju transmisi uap air edible film seperti yang disajikan pada Gambar 1.

Laju transmisi uap air edible film terendah pada perlakuan $\mathrm{A}_{2} \mathrm{~B}_{3} \mathrm{C}_{1}$ dan tertinggi pada perlakuan $\mathrm{A}_{2} \mathrm{~B}_{1} \mathrm{C}_{1}$ seperti yang disajikan pada Gambar 1. Hal ini terjadi terbentuknya ikatan komplek matrik edible film antara senyawa katekin-gliserolCMC-minyak sawit. Asam lemak tidak jenuh dalam minyak sawit akan meregulasi asam-asam lemak dalam struktur matrik edible film lebih merata dan padat, jika konsentrasi minyak sawit lebih tinggi maka makin banyak asam lemak tidak jenuh dalam struktur matrik edible film yang tersebar merata. Diketahui asam lemak tidak jenuh bersifat hidropobik atau non polar, sehingga makin tinggi konsentrasi asam lemak tidak jenuh dalam matrik edible film maka makin sulit uap air dapat menembus edible film. Konsentrasi asam lemak mempunyai efek yang besar terhadap sifat penghambatan terhadap uap air film yang dihasilkan. Semakin banyak asam lemak yang ditambahkan sifat hidrofobiknya akan semakin besar sehingga laju transmisi uap airnya semakin menurun. Hal tersebut dikarenakan migrasi uap air umumnya terjadi pada bagian yang hidrofilik sehingga rasio hidrofilikhidrofobik bahan perlu diperhatikan untuk memperoleh nilai WVTR yang tepat (Garcia, 2000).

Laju transmisi uap air edible film pada penelitian ini sebesar 3,43g. $\mathrm{m}^{-2}$ hari $^{-1}$ lebih rendah jika dibandingkan dengan hasil penelitian Santoso (2011) sebesar 4,27g.m $\mathrm{m}^{-2}$.hari ${ }^{1}$, Santoso dkk. (2012) sebesar 18,25g. $\mathrm{m}^{-2}$.hari ${ }^{-1}$, dan Santoso dkk. (2014) sebesar 4,18g. $\mathrm{m}^{-2} \cdot$ hari $^{-1}$. Perbandingan dari beberapa nilai laju transmisi uap edible film pada penelitian sebelumnya seperti data yang telah dijelaskan diatas maka hasil penelitian ini terjadi perbaikan laju transmisi uap air edible film.

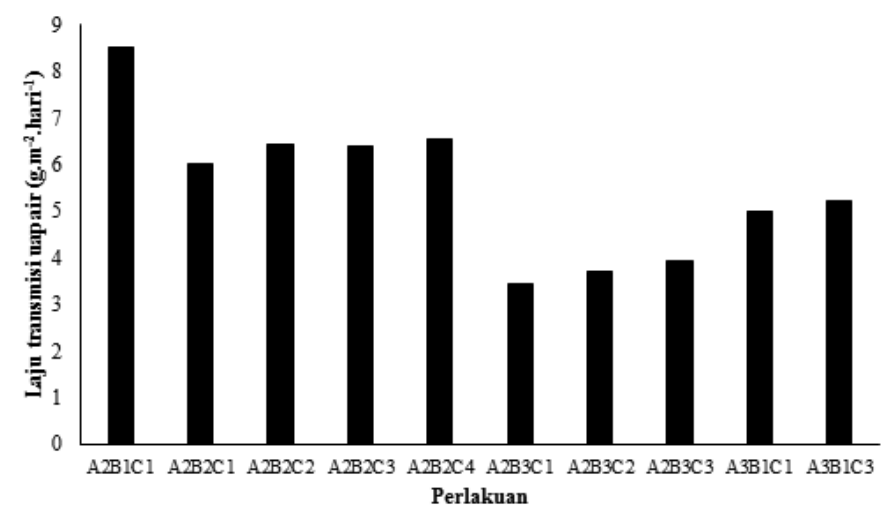

Gambar 1. Nilai rata-rata laju transmisi uap air edible film $\left(\mathrm{g} . \mathrm{m}^{2} \cdot\right.$ hari $\left.^{-1}\right)$ 


\section{Aktivitas Antibakteri}

Uji aktivitas antibakteri menggunakan metode Cakram dengan menggunakan bakteri Staphylococcus aureus yang merupakan indikator higinitas suatu produk pangan. Pengujiannya dilakukan pada 13 sampel yang dipakai berdasarkan karakteristik fisik terbaik untuk edible film. Berdasarkan hasil penelitian hanya ada 6 sampel yang memiliki sifat antibakteri. Hasil pengujian aktivitas antibakteri edible film seperti yang disajikan pada Gambar 2 .

Gambar 2 menunjukkan bahwa perlakuan $\mathrm{A}_{3} \mathrm{~B}_{1} \mathrm{C}_{1}$ menghasilkan edible film dengan diameter daya hambat terhadap bakteri Staphylococcus aureus yang paling tinggi dibanding perlakuan lainnya. Hal ini dijelaskan bahwa dalam matrik edible film banyak gugus hidroksil $(\mathrm{OH})$ bebas dari senyawa katekin. Senyawa katekin merupakan senyawa antibakteri khususnya bakteri Gram-positif dan senyawa ini sangat stabil pada kondisi asam dengan $\mathrm{pH}$ 2,8-4,9 (Pambayun dkk., 2007).

Edible film yang dihasilkan pada penelitian ini memiliki aktivitas antibakteri kategori kuat dengan nilai daerah daya hambat (DDH) sebesar 8,2 mm. Nilai DDH edible film ini mengalami peningkatan dibanding penelitian Santoso (2011) dan Santoso dkk. (2014) yang memanfaatkan ekstrak gambir, namun edible film yang dihasilkan tidak bersifat antibakteri dan Hal ini disebabkan pada penelitian-penelitian ini menggunakan protein. Diketahui bahwa senyawa katekin dari ekstrak gambir memiliki afinitas sangat tinggi terhadap protein, sehingga senyawa katekin melalui gugus hidroksil $(\mathrm{OH})$ berikatan dengan gugus $\mathrm{NH}_{3}$ dari protein. Hal ini mengakibatkan berkurangnya jumlah gugus $\mathrm{OH}$ bebas dari senyawa katekin dalam matrik edible film.

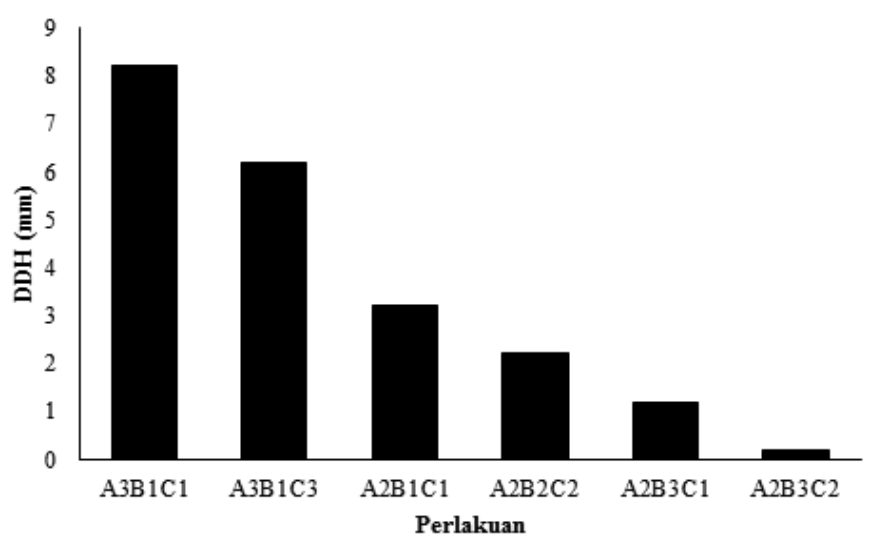

Gambar 2. Diameter daya hambat edible film

\section{KESIMPULAN}

Laju transmisi uap air edible film yang dihasilkan berkisar 8,52-3,43 g.m $\mathrm{m}^{-2}$.hari-1 . Nilai ini lebih baik dibanding penelitian sebelumnya yaitu $18,25 \mathrm{~g} \cdot \mathrm{m}^{-2} \cdot$ hari $^{-1}$. Edible film yang memiliki sifat antibakteri terhadap Staphylococcus aureus dengan nilai diameter daya hambat (DDH) berkisar 0,20 hingga $8,20 \mathrm{~mm}$. Nilai DDH ini lebih baik dari penelitian sebelumnya yaitu $0 \mathrm{~mm}$.

\section{UCAPAN TERIMA KASIH}

Penelitian ini merupakan bagian dari hasil penelitian Hibah Fundamental yang dibiayai dari anggaran DIPA Direktorat Penelitian dan Pengabdian Masyarakat No 023.04.1.673453/2015 tanggal 14 November 2014 DIPA revisi 01 tanggal 03 Maret 2015.

\section{DAFTAR PUSTAKA}

American Society for Testing and Materials. (1997). Annual Book of ASTM Standards. Philadelphia, USA: ASTM.

Campos, C.A., Greshcenson L.N. dan Flores S.K. (2011). Development of edible films and coatings with antimicrobial activity. Food Bioprocess Technology 4: 849-875.

Garcia, A. (2000). Lipid addition to improve barrier properties of edible starch-based films and coating. Journal of Food Science 65(6): 941-947.

Huri, D. dan Nisa, F.C. (2014). Pengaruh konsentrasi gliserol dan ekstrak ampas kulit apel terhadap karakteristik fisik dan kimia edible film. Jurnal Pangan dan Agroindustri 2(4): 29-40.

Jimenez, A., Fabra, M.J., Talens, P. dan Chiralt (2010). Effect of lipid self-association on the microstructure and physical properties of hydroxypropyl-methylcellulose edible films contaning fatty acids. Carbohydrate Polymer 82: 585-593.

Krochta, J.M., Baldwin, E.A. dan Nisperos-Carriedo, M.O. (1994). Edible Coatings and Film to Improve Food Quality. Technomic. Publi. Co. Inc. USA.

Lucida, H. (2006). Determination of the ionization constants and the stability of catechin from gambir (Uncaria gambir (Hunter) Roxb). ASOPMS 12 International Conference. Padang.

Laohakunjit, N. dan Noomhorm, A. (2004). Effect of plasticizer on mechanical and barrier properties of rice starch film. Starch 56: 348-356.

Manab, A. (2008). Pengaruh penambahan minyak kelapa sawit terhadap karakteristik edible film protein whey. Jurnal Ilmu dan Teknologi Hasil Ternak 3(2): 8-16. 
Marta, H., Widyasanti, A. dan Sukarti, T. (2007). Pengaruh Penggunaan Jenis Gula dan Konsentrasi Sari Buah terhadap Beberapa Karakteristik Sirup Jeruk Keprok Garut (Citrus nobilis lour). Laporan Penelitian Dasar, Universitas Padjajaran, Bandung.

Rahim A., Alam, N., Haryadi dan Santoso, U. (2012). Pengaruh konsentrasi pati aren dan minyak sawit terhadap sifat fisik dan mekanik edible film. J. Agroland 17(1): 38-46.

Rodriguez, M., Oses, J., Ziani, K. dan Mate, J.I. (2006). Combined effect of plasticizers and surfactants on the physical properties of starch based edible films. Food Research International 39: 840-846.

Santoso, B. dan Priyanto, G. (2015). Inkoroporasi Senyawa Katekin dan Ekstrak Protein pada Pembentukan Edible Film Fungsional Berbasis Pati. Laporan Kemajuan Penelitian Dasar Univesitas Sriwijaya, Palembang.

Santoso, B., Tampubolon, O.H., Wijaya, A. dan Pambayun, R. (2014). Interaksi $\mathrm{pH}$ dan ekstrak gambir pada pembuatan edible film anti bakteri. Agritech 34(1): 8-13.
Santoso, B., Pratama, F., Hamzah, B. dan Pambayun, R. (2012). Perbaikan sifat mekanik dan laju transmisi uap air edible film dari pati ganyong termodifikasi dengan menggunakan lilin lebah dan surfaktan. Agritech 32(1): 9-14.

Santoso, B. (2011). Integrasi Pati Termodifikasi, Surfaktan, Protein, dan Ekstrak Tanaman Gambit pada Pembuatan Edible Film. Disertasi Program Doktor Ilmu-Ilmu Pertanian Program Pascasarjana. Universitas Sriwijaya, Palembang.

Setyopratomo, P. (2012). Produksi asam lemak dari minyak kelapa sawit dengan menggunakan proses hidrolisis. Jurnal Teknik Kimia 7(1): 26-31.

Tanaka, M., Ishizaki, S., Suzuki, T. dan Takai, R. (2001). Water vapor permeability of edible film prepared from fish water soluble proteins as affected by lipid type. Journal of Tokyo University of Fisheries 87: 31-37. 